\title{
Do Christian Denominations Exhibit Higher Rates of Alcohol Consumption? A Study of Korean American Women in California
}

\author{
D. Eastern Kang Sim • C. Richard Hofstetter • \\ Veronica L. Irvin · John W. Ayers • Caroline A. Macera • \\ Ming Ji • Melbourne F. Hovell
}

Published online: 1 February 2011

(C) The Author(s) 2011. This article is published with open access at Springerlink.com

\begin{abstract}
Although Korean American women show high levels of involvement in religious practices and high prevalence of alcohol consumption, no studies have assessed the association between religious denomination and alcohol intake among this group of women. This cross-sectional study examined the associations of religious denomination and religious commitment to alcohol consumption among Korean American women in California. Polychotomous regression models were used to provide estimates of the associations between religious denomination and religious commitment to alcohol consumption. Catholic Korean American women (OR 5.61 $P<0.01$ ) and Independent Christian women (OR $4.87 P<0.01$ ) showed stronger associations to heavy alcohol consumption when compared to Conservative Christian Korean American women. Path analysis suggested that specific denominations had both direct and indirect effects on the outcome of interest, and that religious commitment and drinking models served as moderators for this phenomenon.
\end{abstract}

D. E. Kang Sim · C. R. Hofstetter $(\bowtie) \cdot$ V. L. Irvin · M. Ji · M. F. Hovell

Center for Behavioral Epidemiology and Community Health, Graduate School of Public Health,

San Diego State University, San Diego, CA, USA

e-mail: rhofstet@mail.sdsu.edu

C. R. Hofstetter

Department of Political Science and the Graduate School of Public Health, San Diego State University,

San Diego, CA, USA

V. L. Irvin

Joint Doctoral Program in Public Health, Health Behavior Science, University of California,

San Diego, CA, USA

V. L. Irvin

San Diego State University, San Diego, CA, USA

J. W. Ayers

Department of Health Behavior and Society, Johns Hopkins Bloomberg School of Public Health,

Baltimore, MD, USA

C. A. Macera · M. Ji · M. F. Hovell

Graduate School of Public Health, San Diego State University, San Diego, CA, USA 
Keywords Religious denomination - Korean American women - Alcohol consumption · Polychotomous regression · Drinking models $\cdot$ Path analysis

\section{Background}

Alcohol is known to display mixed effects on health outcomes. While some studies suggest that moderate alcohol consumption may decrease the risk of diseases such as coronary heart disease (Baum-Baicker 1985; Criqui 1987; Ajani et al. 2000; Solomon et al. 2000), excessive alcohol consumption has shown to increase the risk of certain cancers (Blot et al. 1988; Roberts et al. 1995; Sellers et al. 2001; Singletary and Gapstur 2001), as well as mental suffering (Ahola et al. 2006; Sher 2006; Indig et al. 2007), disturbed social order (Lasky and Ziegenfuss 1979), and lost productivity (McLellan et al. 1996; Godfrey 1997; Rehm et al. 2007).

Religious practices have been associated with several positive health outcomes, such as faster recuperation from acute illness, slower progression of cancer, and protection against cardiovascular disease when mediated by a healthy lifestyle (Thoresen and Harris 2002; Powell et al. 2003; Wink and Dillon 2003). Some studies have suggested that religious beliefs and practices are associated toward lower probabilities of alcohol consumption (Cochran et al. 1988; Koenig et al. 1994). For example, Michalak et al. (2007) concluded that church attendance was associated with abstinence and moderate alcohol consumption, with this relationship mediated by different religious denominations (Michalak et al. 2007). The World Health Organization (WHO) reported public health problems associated with alcohol but eventually concluded that prohibition of alcohol production, sales, and consumption do not succeed unless firmly rooted in the culture and religious beliefs of the population studied (Room 2007). Religion might play a role in prevention of alcohol consumption (WHO 2002) as some cross-sectional studies have reported positive associations with religious practices and less prevalence of common alcohol disorders (Amoateng and Bahr 1986; Bock et al. 1987; Beeghley et al. 1990; Cochran et al. 1992; Koenig et al. 1994; Idler and Kasl 1997; Kendler et al. 1997; Wallace and Forman 1998; Idler et al. 2001). Small-group social support, coping resources, and personal control are assumed to mediate the relationship of religion to abstinence (Ellison and Levin 1998; Pargament et al. 2000; Pendleton et al. 2002; Pargament et al. 2004). However, further studies are needed in order to investigate the relationship between religion and alcoholrelated behaviors, especially among ethno-racial minority groups.

Korean Americans are the third largest population among Asian American Pacific Islander (AAPI) groups in California (US Census 2000), after Chinese and Filipinos. McCracken et al. (2007) reported that Korean American women have the highest alcohol consumption rate among women in all AAPI groups (43.4\%). More than $75 \%$ of Koreans in the United States are affiliated with a Christian church (Won Moo and Kim 1990). A national survey of Presbyterians found that $78 \%$ of Korean Presbyterians attend the congregation's Sunday worship every week, in comparison with $49 \%$ of Latino Presbyterians, 34\% of African American Presbyterians, and 28\% of white Presbyterians (Kim and Kim 2001). Given that high numbers of Koreans are affiliated with Christian churches, high Sunday service attendance rates may be the case with regard to other general Christian denominations. However, no published studies have surveyed an ethnic-specific comparison of the Sunday service attendance rates among other Christian denominations. 
One reason for high attendance includes the vital role that Korean churches serve for this mostly first-generation community. Many Koreans who were not Christian, or who did not attend churches in Korea, attend Korean churches for non-religious purposes such as immigration orientation, social interaction, social networking, and ethnic education for their children (Kwon et al. 1997; Min and Kim 2005). While some studies suggest that religion influences health, no published studies have explored the association of religious participation to alcohol consumption among Korean American women of different Christian denominations. Among Korean American women, high levels of religious church involvement coupled with high rates of alcohol consumption contradict what would be expected from some studies (Resnick et al. 1997).

The purpose of this study was to investigate the association between Christian denominations and alcohol use among a representative sample of adult women of Korean descent residing in California, since doctrinal differences exist among Christian denominations concerning alcohol. The hypothesis that guides this study is that religious participation is differentially related to alcohol consumption by denomination.

\section{Methods}

\section{The Sample}

Data for this analysis were obtained from a larger study of health behaviors in a population-based probability sample of 591 adult (18 years and older) women of Korean descent residing in California (Hofstetter et al. 2004). Koreans in America constitute a population of recent immigrants. Most have come to the United States since immigration reforms were instituted in 1965, and most are first-generation (Min 2006). About 33\% of Koreans in the United States reside in California, and about $65 \%$ of them reside in the greater Los Angeles area.

\section{Procedures}

Culturally appropriate methods were used to adapt the survey from English to Korean, using forward and backward translations. Focus groups and Korean researchers at Myongji and Seoul National Universities reviewed the content, with emphasis given to cultural appropriateness. Survey procedures were pilot-tested and modified prior to implementation.

A representative probability sample of all adult (18 and over) Korean American women in California was interviewed by telephone by bilingual (English/Korean) professional interviewers in 2007, using up to seven callbacks. Participants were sampled from those with residential telephones, utilizing a list of persons in California with Korean surnames that was purchased from a commercially available telephone subscriber list which was developed from many sources in addition persons listed in telephone directories. The list included persons on the federal do not call list and cell phones. All contacts were screened for Korean descent, but not by citizenship. Selection of respondents was based on the adult female of Korean descent with the most recent birthday. The Korean or English language was used as per respondents' preference. Interviews were completed with approximately $65 \%$ of eligible respondents contacted. All study procedures were approved by the San Diego State University Institutional Review Board. 
Sampling procedures resulted in minor underrepresentation of women ages 18-34 and overrepresentation of women ages 35-54. Data were weighted by age to compensate for this bias. No significant differences in conclusions appeared when analysis was replicated using unweighted data.

Drinking

Based on the 2005 Dietary Guidelines for Americans (US Department of Health and Human Services and US Department of Agriculture 2005) for women, abstinence and moderate and heavy alcohol consumption were established from the responses to "About how many drinks containing alcohol do you have on a typical day when you have something to drink? A drink of alcohol is one $12 \mathrm{oz}$ glass, can, or bottle of beer, one 4-5 oz glass of wine, one $12 \mathrm{oz}$ can or bottle of wine cooler, one shot, or one mixed drink with one shot of liquor (i.e., vodka, rum, whiskey or soju)." Participants were coded so that "abstainers" (coded as 1) reported drinking less than 0.005 drinks per day, "moderate drinkers" (coded as 2) up to one drink a day, and "heavy drinkers" (coded as 3) reported drinking more than one drink per day.

\section{Covariates}

Two key religion variables were measured: religious denomination and religious commitment.

\section{Religious Denomination}

Religious denomination was measured from responses to "What is the name and location of your current place of worship?" Participants were initially classified as reporting a religion or not, and the former were then classified by denomination based on codes from National Election Studies (NES) developed by the University of Michigan. Final classifications were determined by the senior author, who is an expert on Korean religions. Denominations were then grouped into Presbyterian, Catholic, and Christian independent denominations and also grouped into low-frequency denominations including "conservative "(e.g., Baptist, Evangelical, and Holiness) and "moderate" (e.g., Methodist, Reformed, and Lutheran) faith groups, based on the National Opinion Research Center's classification of Protestant denominations (Smith 1990). Self-classified "no religion" respondents were also included in analysis. Analysis was based on the $N=555$ who reported Christian religious affiliation or self-classified as "no religion."

\section{Religious Commitment}

Religious commitment was measured by responses to "How many days during a typical month do you pray or meditate?" "How many days during a typical month do you spend reading your religion's primary text (e.g., Bible, Qur'an, Sutras, etc.)?" and “About how often do you attend religious services during an average month?" A composite commitment measure (mean $=.22 \pm 2.25$, Cronbach's $\alpha=.62$ ) was formed by summing responses after each variable had been standardized (mean $=0.0 \pm 1.0$ ). A composite score was formed using a composite commitment measure by coding those who scored 1 or greater as 1 , and others as 0 . 


\section{Drinking Models}

A measure of drinking models was based on responses to "Would you say that any of the following have a problem with drinking too much alcohol: Spouse or partner? Parents/ parents-in-law? Siblings? Friends? Children? Grandchildren? Other?" Yes responses were then summed to create a total score for those who were reported to have problems with drinking too much alcohol. The composite was then dichotomized to yes or no to constrain skewness.

\section{Demographic Variables}

Age, gender, years of education in Korea and the United States, years of residence in Korea and in the United States, and work outside of the home were measured by self-report.

Analysis

Statistics were computed using SPSS 15 (SPSS Inc, Chicago, IL) and SAS 9.1 (SAS Institute Inc, Cary, NC). Polychotomous regression models were used to provide estimates of the associations of religious denomination and religious commitment to alcohol consumption.

Path analyses were used as supplementary analyses to assess the multiple and interrelated dependence relationship of risk factors to alcohol consumption. This method used the maximum likelihood of parameter estimation. SAS PROC CALIS was used to model path analyses. Collinearity tests were computed prior to estimating regressions through inspection of a pairwise correlation matrix.

\section{Findings}

Participants

Over $90 \%$ of surveys were conducted in Korean (see Table 1). The mean age for the sample was 45.9 years $(\mathrm{SD}=14.4)$, ranging from 18 to 94 years, the mean years residing in Korea was 28.1 years $(\mathrm{SD}=13.4)$, and the mean years residing in the United States was 17.6 years $(\mathrm{SD}=10.1)$. About $37.7 \%$ of respondents worked outside the home and $77.7 \%$ were married.

About $40 \%$ of participants reported abstinence from alcohol, $44.3 \%$ were moderate drinkers, and $15.5 \%$ were heavy drinkers. Over $90 \%$ reported attending church with affiliation to Christian denominations. Presbyterian (38.4\%) and Catholic (13.3\%) were the largest single denominations, while diverse independents $(8.5 \%)$, conservative faith groups (20.9\%), and moderate faith groups $(10.3 \%)$ constituted the rest. Nearly $9 \%$ of participants reported no religion.

\section{Multivariate Analysis}

Moderate and heavy alcohol consumption was regressed on church affiliation using a polychotomous regression, with abstinence as the reference category. Collinearity tests revealed no strong sign of collinearity. Tolerances ranged from 0.671 (age) to 0.979 (drinking models), suggesting low levels of multicollinearity. 
Table 1 Demographic characteristics of the final sample of 555 Korean American women in California 2007

\begin{tabular}{lll}
\hline Demographic & Mean & SD \\
\hline Age of respondent & 45.9 & 14.4 \\
Years resident in Korea & 28.1 & 13.4 \\
Years resident in US & 17.5 & 10.1 \\
Years education in Korea & 12.6 & 4.7 \\
Years education in US & 2.4 & 4.4 \\
& Percent & \\
Working outside the home & 37.7 & \\
Born in Korea & 97 & \\
Parents born in Korea & 99.3 & \\
Interviewed in Korean language & 91.9 & \\
Marital status & & \\
Single & 12.5 & \\
Married & 77.9 & \\
Widowed & 5.8 & \\
Divorced & 3.6 & \\
Other & 0.2 & \\
\hline
\end{tabular}

Table 2 Unadjusted polychotomous regression of the relation between religious denominations with three levels of alcohol drinking categories (abstainer is reference) among 555 Korean American women in California 2007

\begin{tabular}{|c|c|c|c|c|c|c|}
\hline \multirow[t]{3}{*}{ Variable } & \multicolumn{6}{|c|}{ Alcohol-drinking pattern } \\
\hline & \multicolumn{3}{|c|}{ Heavy versus abstainer (ref) } & \multicolumn{3}{|c|}{ Moderate versus abstainer (ref) } \\
\hline & OR & $95 \% \mathrm{CI}$ & $P$-value & OR & $95 \% \mathrm{CI}$ & $P$-value \\
\hline \multicolumn{7}{|l|}{ Religious denominations $^{\mathrm{a}}$} \\
\hline Presbyterian & 2.26 & $(0.97,5.26)$ & 0.059 & 0.89 & $(0.55,1.45)$ & 0.659 \\
\hline Catholics & 5.32 & $(2.01,14.03)$ & 0.001 & 1.43 & $(0.74,2.77)$ & 0.28 \\
\hline Independent & 4.33 & $(1.52,12.29)$ & 0.006 & 0.87 & $(0.40,1.88)$ & 0.736 \\
\hline Moderate faith group & 1.16 & $(0.34,3.88)$ & 0.809 & 0.79 & $(0.41,1.55)$ & 0.5 \\
\hline No religion group & 6.5 & $(2.12,19.89)$ & 0.001 & 2.19 & $(0.98,4.88)$ & 0.054 \\
\hline
\end{tabular}

a The conservative faith group is the reference category

Catholic women were significantly more likely to be classified as heavy drinkers than women in the conservative faith group $(\mathrm{OR}=5.32, P<.0 .001$, Table 2$)$. Compared to women in the conservative faith group, women who associated with an independent religious group were also more likely to be heavy drinkers $(\mathrm{OR}=4.33, P<0.01)$. Korean American women who self-classified as 'no religion' showed the highest risk $(\mathrm{OR}=6.50$, $P<0.001)$ of being heavy drinkers, in comparison with conservative faith women. No statistically significant distinctions appeared for moderate drinking among denominations.

After adjusting for all covariates, associations between religious denomination and alcohol consumption levels proved robust (Table 3). The odds of being a heavy drinker among Catholic Korean American women were five times more likely $(P<.001)$ than the odds of the conservative faith group, while the odds of women affiliated with independent Christian groups being heavy drinkers $(P<.01)$ were four times the odds of the 
Table 3 Adjusted polychotomous regression of the relation between religious denominations with three levels of alcohol drinking categories (abstainer is reference) among 555 Korean American women in California 2007

\begin{tabular}{|c|c|c|c|c|c|c|}
\hline \multirow[t]{3}{*}{ Variable } & \multicolumn{6}{|c|}{ Alcohol-drinking pattern } \\
\hline & \multicolumn{4}{|c|}{ Heavy versus abstainer (ref) } & \multicolumn{2}{|c|}{ Moderate versus abstainer (ref) } \\
\hline & OR & $95 \% \mathrm{CI}$ & $P$-value & OR & $95 \% \mathrm{CI}$ & $P$-value \\
\hline \multicolumn{7}{|l|}{ Religious denominations $^{\mathrm{a}}$} \\
\hline Presbyterian & 2.37 & $(0.99,5.65)$ & 0.051 & 0.92 & $(0.56,1.51)$ & 0.759 \\
\hline Catholics & 5.61 & $(2.06,15.28)$ & 0.001 & 1.43 & $(0.72,2.84)$ & 0.294 \\
\hline Independent & 4.87 & $(1.63,14.49)$ & 0.004 & 0.80 & $(0.36,1.76)$ & 0.586 \\
\hline Moderate faith group & 1.23 & $(0.35,4.26)$ & 0.735 & 0.83 & $(0.42,1.66)$ & 0.608 \\
\hline No religion group & 4.76 & $(1.50,15.11)$ & 0.008 & 1.80 & $(0.79,4.11)$ & 0.160 \\
\hline Religious commitment ${ }^{\mathrm{b}}$ & 0.60 & $(0.31,1.19)$ & 0.146 & 0.83 & $(0.54,1.29)$ & 0.430 \\
\hline Drinking model & 1.77 & $(1.02,3.08)$ & 0.041 & 1.49 & $(1.01,2.18)$ & 0.041 \\
\hline Age & 0.97 & $(0.95,1.00)$ & 0.061 & 0.98 & $(0.97,1.00)$ & 0.086 \\
\hline Education & 1.00 & $(0.83,1.19)$ & 0.998 & 1.17 & $(1.03,1.34)$ & 0.014 \\
\hline Work outside the home & 2.24 & $(1.29,3.88)$ & 0.004 & 1.28 & $(0.86,1.91)$ & 0.223 \\
\hline Married & 0.81 & $(0.41,1.56)$ & 0.529 & 1.58 & $(0.97,2.57)$ & 0.062 \\
\hline Years in the US & 0.98 & $(0.95,1.01)$ & 0.269 & 1.00 & $(0.98,1.02)$ & 0.545 \\
\hline
\end{tabular}

\footnotetext{
${ }^{a}$ The conservative faith group is the reference

${ }^{\mathrm{b}}$ Religious commitment is a composite measure of days of religious reading, church attendance, and number of prayers per day
}

conservative faith group. The odds of women who reported "no religion" being heavy drinkers $(P<0.01)$ were also four times that of the conservative faith women being heavy drinkers. Those who had family or friends with drinking problems (drinking models) were more likely to be heavy or moderate drinkers than those who had no family or friends with drinking problems $(P<0.05)$. Working outside the home $(P<.001)$ was also associated with heavy drinking among Korean American women after controlling for other variables.

\section{Path Analysis}

As hypothesized, the initial model showed a significant path from 'religious denomination' to 'alcohol consumption' in the positive direction. Fit indices, however, implied that the overall model was not acceptable, and tests involving Lagrange multipliers suggested an alternative model. Figure 1 presents the alternative model based on this analysis. Alcohol consumption was related to being a Korean American woman who classified as Catholic, independent Christian denomination, no religion, and working outside of the home.

Religious commitment showed a negative association to alcohol consumption, while the presence of a drinking model showed a positive association. Korean American women who self-classified as Catholics or no religion were associated with lower religious commitment, while number of years in the Unites States was associated with higher religious commitment. Korean American women who self-classified as Catholics or no religion were positively associated with the presence of a drinking model, which in turn was associated with higher alcohol consumption. Religious commitment and drinking models acted as moderators for Korean American women who were self-classified as Catholics or no 


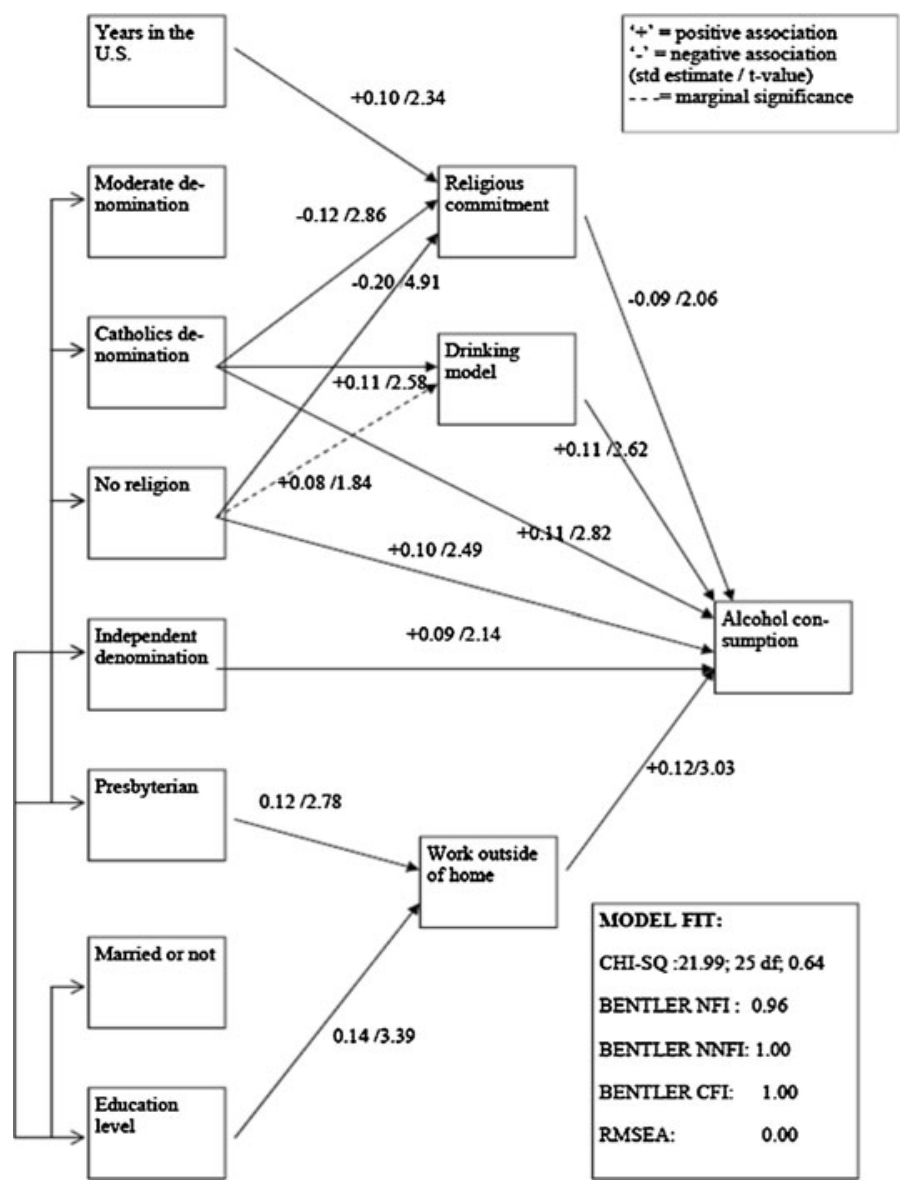

Fig. 1 Path analysis of religious denomination (ref. Conservative faith group) to alcohol consumption in Korean American WOMEN in California 2007

religion. Korean American women who worked outside of home were more likely to score high on alcohol consumption. Education level and Presbyterian self-classification among Korean American women were positively associated with work outside of the home. Working outside of the home served as a mediator between Korean American women who self-classified as Presbyterian and alcohol consumption.

\section{Discussion}

Women's drinking patterns are highly related to cultural norms and practices of the ethnic groups to which they belong (Lorraine Collins and Muraven 2003). A significant transition of cultural norms and practices can be observed among traditional Korean American women, in which the atheist majority is converted to Christian church attendance after immigrating to the United States (Kwon et al. 2001). Our path analysis suggested that specific denomination had both direct and indirect effects on the outcome of interest and 
that religious commitment and the presence of a drinking model served as moderators for this phenomenon.

It is generally true that unhealthy habits such as heavy alcohol consumption are generally discouraged in religious teaching. However, not all Christian denominations share the same specific doctrines nor emphasize them to the same degree. Views concerning alcohol consumption vary by denomination. Fundamentalists and evangelicals proclaim that abstinence from alcohol is proscribed by the Bible. According to a report from General Council of the Assemblies of God, "a little alcohol is too much since drinking in moderation provides Satan an opening to cruel deception." (General Presbytery of the Assemblies of God 1985) On the other hand, a moderate position is held by Roman Catholics, Eastern Orthodox, Lutherans, and Reformed Churches. The Catholic Church also teaches that alcohol consumption is acceptable in moderation (Americancatholic.org 1996). Independent Christian denominations, which find no root in conservative Christian denominations, would not regulate such action; therefore, its members are more likely to consume alcohol.

This study shows that the type of Christian denomination substantially predicted the probability of alcohol consumption among Korean American women in California. Korean American women who were affiliated with Christian denominations (e.g., Catholics and Independents) permitting alcohol consumption show the highest probability of alcohol use. The risk of being a heavy alcohol drinker was greater than the secular "no religion" group after controlling for other variables in the analysis among Catholics.

Doctrinal teachings seem especially influential once we understand the differences between American and Korean cultures (Pai et al. 1987). American culture is individualcentered and emphasizes individual rights, while Korean culture centers on values such as social duties and responsibilities. A Korean church member, for example, may place a high emphasis on roles of different hierarchical positions. Korean churches often have different hierarchical positions, such as a pastor, an elder, a deacon, and a church member. It is their duty to perform appropriate functions in order to follow the doctrines and the teachings of the head minister. The messages delivered by the minister, therefore, become commands for the church congregation to follow. Also, while American culture is relatively more egalitarian in this context-depicting others as equals in terms of authority-Korean culture is characterized by stronger hierarchical relationships of authority. In this case, congregations emphasize docility toward the minister of the church. In this study, the minister's discouragement of alcohol consumption was not significant. It is important for future studies to explore the role of the minister as a source of health-related messages.

In addition to the different doctrinal teachings about alcohol consumption, ethnic Korean Christian denominations may also influence health behavior in several ways. For example, involvement with religious services provides many different opportunities for an individual to remain in social contact with others and to participate in volunteer or educational groups. This is especially true among Korean immigrants to the United States, since many did not attend Christian church services in Korea but may attend a Korean ethnic church for various purposes such as immigration orientation, social interaction/ support, social networks, and ethnic education for their children in addition to religious practices (Min 1992).

Findings of other studies suggest that religious affiliations can result in larger social networks and provide additional social networking and support for members of an organization (Ellison and George 1994; Ayers 2008). This might lead to better health-related resources and positive health outcomes (House et al. 1988). Social involvement might also 
act as a positive reinforcement for alcohol use if the doctrines and members of a denomination support the use of alcohol.

In addition to differences in drinking patterns among Korean American women from several denominations, this study explored a possible mechanism involving religious affiliation and social reinforcement using path analysis. Results of this study imply that compared to Korean American women in conservative faith denominations, Korean Catholic women are at greater risk of consuming alcohol due to their lower level of religious commitment and their greater likelihood of knowing someone who has a drinking problem. The same phenomenon can be observed in Korean American women who report no religion. These results also show that working outside of the home mediates the relationship between Presbyterians and alcohol consumption.

The path suggests that social reinforcements such as the presence of a drinking model or work outside of home may have greater influence on the drinking habits of Korean American women than the protective factor of religious commitment.

Our study supports the hypothesis that alcohol problems are found less often among people who belong to more conservative denominations. Cahalan and Room (Cahalan and Room 1972) reported that among American Catholics and liberal Protestants such as Presbyterians, relatively few abstainers from alcohol existed, while many heavy drinkers existed. However as noted below, Korean Presbyterians differ from non-Korean Presbyterians because they are more conservative on doctrinal issues, although more liberal than fundamentalists. They also reported that fewer alcohol problems existed among those who attend religious services regularly than those who do not. This study provides a possible empirical mechanism through path analysis that supports previous findings from a national study of how religion relates strongly to drinking behavior (Cahalan and Room 1972; Michalak et al. 2007). To our knowledge, this is the only study conducted of the Korean American ethnic group in relation to religious denominations and health behavior.

\section{Limitations}

Due to the sample size, denominations with low sample sizes could not be isolated in the model in comparison with Presbyterians and Catholics, and classifications have simplified doctrinal groups of Protestants. In some instances, it was clear that respondents reported a denomination that did not match the denomination of the church attended-a phenomenon rare among longer term residents of the United States. Accurate classification was conducted by the first author checking the church denomination according to the address of the church. In addition, this study did not explore the classification of sub-denominations within a general denomination. For example, there were four major sub-denominations within Presbyterians: Presbyterian Church in the USA (PCUSA), Presbyterian Church in America (PCA), Korean American Presbyterian Church (KAPC), and Korean Presbyterian Church in America/Abroad (KPCA). Smith (1990) classified PCUSA as liberal and PCA as moderate faith group, but no classification was available for KAPC or KPCA. We justified the faith group of both KAPC and KPCA to be the same as PCUSA based on their same membership in World Alliance of Reformed Church and/or by sharing the same creedal formulations of faith (Anderson 2008; General Secretary 2008). Although PCA is classified as 'moderate' faith group, due to its differences in the creeds of faith to Methodist and Lutheran, all Presbyterian denominations in this present study were collapsed into one body as a consolidation of Presbyterians and coded the same.

It is important to realize that doctrine in Korean Presbyterian churches differs considerably from that of non-Korean Presbyterian denominations in the United States. While 
Smith's classification for Presbyterian churches in the United States is based on its theological liberalism from the Protestant mainline; one must take into account that Korean Presbyterians are more doctrinally conservative than non-Korean Presbyterian denominations. One reason the Korean American Presbyterian church has more conservative character can be traced back to American missionaries. Presbyterian missionaries introduced the Bible in Hangul into Korea so that less-educated people could read the Bible and, thus, converted a large numbers of Koreans. Most of these missionaries emphasized the inerrant character of the Bible and strict standards of morality (Hunt 1980). Korean ethnic Presbyterian churches follow a belief structure (Anderson 2008; General Secretary 2008), which more liberal Christians and non-Korean Presbyterian churches do not. Liberal forms of Christianity, for example, do not espouse the belief in the propositional inerrancy of scripture (Gruber 1910).

Future studies exploring these specific sub-denominations of each general denomination, especially among Presbyterians, will help to clarify how the religious doctrines relate to health. Despite the path analysis, this study was based on cross-sectional data and did not provide evidence of life-course causality, and a longitudinal design may clarify the religion-health relationship. Finally, the sample was collected using Korean surnames, and Korean American women whose surname changed due to marriage or other reasons were not represented in this study. However, the data were generally representative of demographic information for Korean American women in the United States Census for California.

\section{Future Studies}

Scholars have reported the functions of Korean-specific churches to be more than a place of religious worship among Korean American women in California (Hurh and Kim 1990; Min 1992). Studies must further explore whether a behavioral transition continues for second-generation Korean Americans. These studies can test the role of ethnic-specific churches in relation to alcohol consumption and other health risks as the generations change.

In addition, researchers should attempt to understand the behavioral mechanisms involved in the influence of religion on Korean American health behavior by exploring characteristics of Koreans who married members of other racial/ethnic groups. And studies should also explore how cultural fusion influences participation in religious services as well as risky health behaviors. Also, a life-course approach of this first generation could be helpful in exploring since 'years in the US' showed a positive association to 'religious commitment' in our path diagram.

Cooperative interventions linking health care providers with religious institutions may be extremely fruitful in the pursuit of more knowledge. Knowledge about how religious groups promote health behavior can serve a practical use in prevention and treatment programs and lead to a better understanding of the role of protective factors. It is particularly important to expand knowledge of mechanisms by which religious denominations influence health behaviors. Longitudinal designs will bolster the findings beyond religious variables and religious denominations, and they can clarify the influence of religion on health as well as the more general relationship between the two phenomena.

Acknowledgments The project described was supported by the Grant Number R01CA105199 to C. Richard Hofstetter from the National Cancer Institute. The content is solely the responsibility of the authors and does not necessarily represent the official views of the National Cancer Institute or the National 
Institutes of Health. Intramural support from was received from the Center for Behavioral Epidemiology and Community Health, San Diego State University.

Open Access This article is distributed under the terms of the Creative Commons Attribution Noncommercial License which permits any noncommercial use, distribution, and reproduction in any medium, provided the original author(s) and source are credited.

\section{References}

Ahola, K., Honkonen, T., et al. (2006). Alcohol dependence in relation to burnout among the Finnish working population. Addiction, 101(10), 1438-1443.

Ajani, U. A., Gaziano, J. M., et al. (2000). Alcohol consumption and risk of coronary heart disease by diabetes status. Circulation, 102(5), 500-505.

Americancatholic.org. (1996). Ask the wise man: History isn't always clear St. Anthony Messenger Magazine, May, from http://www.americancatholic.org/Messenger/May1996/Wiseman.asp\#F3.

Amoateng, A. Y., \& Bahr, S. J. (1986). Religion, family, and adolescent drug use. Sociological Perspectives, 29(1), 53-76.

Anderson, M. H. (2008). Creeds of Christendom. Retrieved April, 2010, from http://www.creeds.net/ index.htm.

Ayers, J. W. (2008). Religious messages may diminish the use of alcohol: A report about women in California of Korean descent. San Diego State University: San Diego.

Baum-Baicker, C. (1985). The health benefits of moderate alcohol consumption: A review of the literature. Drug and Alcohol Dependence, 15(3), 207-227.

Beeghley, L., Bock, E. W., et al. (1990). Religious change and alcohol use: An application of reference group and socialization theory. Sociological Forum, 5(2), 261-278.

Blot, W. J., McLaughlin, J. K., et al. (1988). Smoking and drinking in relation to oral and pharyngeal cancer. Cancer Research, 48(11), 3282-3287.

Bock, E. W., Cochran, J. K., et al. (1987). Moral messages: The relative influence of denomination on the religiosity-alcohol relationship. The Sociological Quarterly, 28(1), 89-103.

Cahalan, D., \& Room, R. (1972). Problem drinking among American men aged 21-59. American Journal of Public Health, 62(11), 1473-1482.

Cochran, J. K., Beeghley, L., \& Bock, E. W. (1988). Religiosity and alcohol behavior: An exploration of reference group theory. Sociological Forum, 3(2), 256-276.

Cochran, J. K., Beeghley, L., et al. (1992). The influence of religious stability and homogamy on the relationship between religiosity and alcohol use among Protestants. Journal for the Scientific Study of Religion, 31(4), 441-456.

Criqui, M. H. (1987). The roles of alcohol in the epidemiology of cardiovascular diseases. Acta Medica Scandinavica, 717, 73-85.

Ellison, C. G., \& George, L. K. (1994). Religious involvement, social ties, and social support in a Southeastern community. Journal for the Scientific Study of Religion, 33(1), 46-61.

Ellison, C. G., \& Levin, J. S. (1998). The religion-health connection: Evidence, theory, and future directions. Health Education \& Behavior, 25(6), 700-720.

General Presbytery of the Assemblies of God. (1985). A biblical perspective on abstinence.

General Secretary, K. A. P. C. (2008). Korean American Presbyterian church. Retrieved April, 2010, from http://www.kapc.org/gb/aboutus.php.

Godfrey, C. (1997). Lost productivity and costs to society. Addiction, 92 Suppl 1: S49-S54.

Gruber, H. (1910). Liberalism. The catholic encyclopedia retrieved July 14, 2010, from http://www.newadvent.org/cathen/09212a.htm.

Hofstetter, C. R., Hovell, M. F., et al. (2004). Tobacco use and acculturation among Californians of Korean descent: A behavioral epidemiological analysis. Nicotine \& Tobacco Research, 6(3), 481-489.

House, J. S., Landis, K. R., et al. (1988). Social relationships and health. Science, 241(4865), 540-545.

Hunt, E. N. (1980). Protestant pioneers in Korea. Maryknoll, NY: Oris Books.

Hurh, W., \& Kim, K. (1990). Religious participation of Korean immigrants in the United States. Journal for the Scientific Study of Religion, 29(1), 19-34.

Idler, E. L., \& Kasl, S. V. (1997). Religion among disabled and nondisabled persons II: Attendance at religious services as a predictor of the course of disability. Journals of Gerontology. Series B, Psychological Sciences and Social Sciences, 52(6), S306-S316. 
Idler, E. L., Kasl, S. V., et al. (2001). Patterns of religious practice and belief in the last year of life. Journals of Gerontology. Series B, Psychological Sciences and Social Sciences, 56(6), S326-S334.

Indig, D., Eyeson-Annan, M., et al. (2007). The effects of alcohol consumption, psychological distress and smoking status on emergency department presentations in New South Wales, Australia. BMC Public Health, 7(147), 46.

Kendler, K. S., Gardner, C. O., et al. (1997). Religion, psychopathology, and substance use and abuse; A multimeasure, genetic-epidemiologic study. American Journal of Psychiatry, 154(3), 322-329.

Kim, K. C., \& Kim, S. (2001). The Ethnic roles of Korean immigrant churches in the United Sates. In K. C. Kim, R. S. Warner, \& H. Y. Kwon (Eds.), Korean American and their religions: Pilgrims and missionaries from a different shore. University Park: Pennsylvania State University Press.

Koenig, H. G., George, L. K., et al. (1994). Religious practices and alcoholism in a Southern adult population. Hosp Community Psychiatry, 45(3), 225-231.

Kwon, H., Kim, K., et al. (2001). Korean Americans and their religions: Pilgrims and missionaries from a different shore. Pennsylvania State Univ Pr.

Kwon, V. H., Ebaugh, H. R., et al. (1997). The structure and functions of cell group ministry in a Korean Christian church. Journal for the Scientific Study of Religion, 36(2), 247-256.

Lasky, D. I., \& Ziegenfuss, J. T., Jr. (1979). Anomie and drug use in high school students. International Journal of Addictions, 14(6), 861-866.

Lorraine Collins, R., \& Muraven, L. D. (2003). Minority women and alcohol use. National Institute on Alcohol Abuse and Alcoholism.

McCracken, M., Olsen, M., et al. (2007). Cancer incidence, mortality, and associated risk factors among Asian Americans of Chinese, Filipino, Vietnamese, Korean, and Japanese ethnicities. CA Cancer Journal for Clinicians, 57(4), 190-205.

McLellan, A. T., Woody, G. E., et al. (1996). Evaluating the effectiveness of addiction treatments: Reasonable expectations, appropriate comparisons. Milbank Quarterly, 74(1), 51-85.

Michalak, L., K. Trocki, et al. (2007). Religion and alcohol in the US National Alcohol Survey: How important is religion for abstention and drinking? Drug Alcohol Depend, 87(2-3):268-280.

Min, P. G. (1992). The structure and social functions of Korean immigrant churches in the United States. International Migration Review, 26(4), 1370-1394.

Min, P. G. (2006). Asian Americans contemporary trends and issues. Pine Forge Press: Thousand Oaks.

Min, P. G., \& Kim, D. Y. (2005). Intergenerational transmission of religion and culture: Korean protestants in the U.S. Sociology of Religion, 66(3), 263-282.

NES. "Religion 1990 and Later." from http://www-personal.umich.edu/ wmebane/ps389/anes_cdf_app/ node13.html.

Pai, Y. D., Pemberton, D., \& Worley, J. (1987). Findings on Korean American early adolescents and adolescents. Kansas City: University of Missouri School of Education.

Pargament, K. I., Koenig, H. G., et al. (2000). The many methods of religious coping: Development and initial validation of the RCOPE. Journal of Clinical Psychology, 56(4), 519-543.

Pargament, K. I., Koenig, H. G., et al. (2004). Religious coping methods as predictors of psychological, physical and spiritual outcomes among medically ill elderly patients: A two-year longitudinal study. Journal of Health Psychology, 9(6), 713-730.

Pendleton, S. M., Cavalli, K. S., et al. (2002). Religious/spiritual coping in childhood cystic fibrosis: A qualitative study. Pediatrics, 109(1), E8.

Powell, L. H., Shahabi, L., et al. (2003). Religion and spirituality. Linkages to physical health. American Psychologist, 58(1), 36-52.

Rehm, J., Gnam, W., et al. (2007). The costs of alcohol, illegal drugs, and tobacco in Canada, 2002. Journal of Studies on Alcohol Drugs, 68(6), 886-895.

Resnick, M. D., Bearman, P. S., et al. (1997). Protecting adolescents from harm. Findings from the National Longitudinal study on adolescent health. Jama, 278(10), 823-832.

Roberts, B. J., Shoaf, S. E., et al. (1995). Rapid changes in cytochrome P4502E1 (CYP2E1) activity and other P450 isozymes following ethanol withdrawal in rats. Biochemical Pharmacology, 49(11), $1665-1673$.

Room, R. (2007). WHO expert committee on problems related to alcohol consumption: Second report.

Sellers, T. A., Kushi, L. H., et al. (2001). Dietary folate intake, alcohol, and risk of breast cancer in a prospective study of postmenopausal women. Epidemiology, 12(4), 420-428.

Sher, L. (2006). Alcohol and suicide: Neurobiological and clinical aspects. ScientificWorldJournal, 6, 700-706.

Singletary, K. W., \& Gapstur, S. M. (2001). Alcohol and breast cancer: Review of epidemiologic and experimental evidence and potential mechanisms. Jama, 286(17), 2143-2151.

Smith, T. W. (1990). Classifying Protestant denominations. Review of Religious Research, 31(3), $225-245$. 
Solomon, C. G., Hu, F. B., et al. (2000). Moderate alcohol consumption and risk of coronary heart disease among women with type 2 diabetes mellitus. Circulation, 102(5), 494-499.

Thoresen, C. E., \& Harris, A. H. (2002). Spirituality and health: What's the evidence and what's needed? Annals of Behavioral Medicine, 24(1): 3-13.

US Department of Health and Human Services and US Department of Agriculture. (2005). Alcohol beverages. Washington, DC: US Government Printing Office.

Wallace, J. M., Jr., \& Forman, T. A. (1998). Religion's role in promoting health and reducing risk among American youth. Health Education \& Behavior, 25(6), 721-741.

WHO. (2002). Development of projects for prevention of harm from alcohol abuse. World Health Organization.

Wink, P., \& Dillon, M. (2003). Religiousness, spirituality, and psychosocial functioning in late adulthood: Findings from a longitudinal study. Psychology and Aging, 18(4), 916-924. 